\begin{tabular}{|c|c|c|}
\hline \multirow{2}{*}{\multicolumn{2}{|c|}{\begin{tabular}{l|l} 
DE & DE GRUYTER \\
& OPEN
\end{tabular}}} & ECONOMIC THEMES (2017) 55(2): 161-178 \\
\hline & & DOI 10.1515/ethemes-2017-0010 \\
\hline
\end{tabular}

\title{
TAX AUDIT AS A SIGNIFICANT FACTOR IN SUPPRESSING TAX EVASION

\author{
Miodrag Todorović
}

Tax Administration, Office Leskovac, Republic of Serbia

$\triangle$ miodragtodorovic61@gmail.com

\section{Ivan Stanković}

Tax Administration, Office Leskovac, Republic of Serbia

$\bowtie$ ivan.bstankovic@gmail.com

\section{Samir Ljajić}

International University of Novi Pazar, Department of Economic Sciences, Republic of Serbia

UDC

336.228 .34

Review

paper
Received: 22.08.2016. Accepted: 25.04.2017.

\author{
$\bowtie$ ljajics@gmail.com
}

Abstract: The fact that an enormous portion of the public revenue is lost through tax evasion indicates the inevitability of taking various measures to suppress it. According to the latest statistics, the outflow from the gross domestic product through tax evasion is $30 \%$. The aim of this paper is to point to the systematisation of the matter relating to an assessment of the efficiency of tax audit as a pillar of the reduction of tax evasion and informal economy in our country. Methodology implies a descriptive research. Collected data were meticulously analysed by means of basic arithmetic operations. Due to serious consequences of tax evasion, it is necessary to upgrade the tax system modelled on developed market economies. It is necessary to modernise a Tax Administration, as well as to improve the co-operation between its segments. A synthetic income tax should be introduced. It would encompass all revenues that a taxpayer generates per year. If all taxpayers settled their tax liabilities, it would create space for tax burden reduction. In legal states only "the bravest" resort to tax evasion. Most countries have undertaken a series of measures in order to suppress tax evasion and informal economy. However, the effectiveness of the struggle varies.

Keywords: tax, tax evasion, suppression, tax audit, tax system.

JEL classification: H26 


\section{Introduction}

The origin of the term evasion is in the Latin word evadere, which means escape, i.e. avoidance. Tax evasion exists in all countries and in all systems. It can be caused by various factors and have different consequences. In recent years one is a witness to frequent financial transactions which primarily aim at tax evasion. These transactions are one of the main characteristics of informal economy, i.e. one of its most significant manifestations.

Everything relating to taxes and taxation has always been shrouded in mystery, at least for a wide circle of taxpayers. One concurrently knows a little and a lot about tax and its effects, and this contradiction defines one's relationship towards fiscal obligations. The reluctance to accept tax liabilities arises from their compulsory character, as well as from the fact that there is no visible compensation in return, which is present in some other social obligations. The purport of such attitude is perhaps most eloquently expressed by the following thought: The actual benefit of honesty is a higher tax burden...

Paying taxes creates conditions for a normal life in the social community, as well as for the progress of civilisation. The means collected through all forms of public revenue run as a kind of red thread through all aspects of social life and without their regular flow the functioning of the state mechanism would come to a halt. It is, therefore, in the interest of every modern state to make as many taxpayers as possible to meet their obligations through public revenue. Irregular, untimely or incomplete tax payments or a complete absence of tax payments and other public revenues results in various forms of evading taxes and other public revenues.

Tax evasion, as an economic and financial phenomenon, appears as one of the effects of the taxation process the importance of which emerges from possible consequences in social and economic life (Harvey, 2002, p.325).

Regardless of the popularity and significance of the aforementioned phenomenon for the achievement of various goals of the fiscal and general economic policies, tax evasion has not been given sufficient attention in the fiscal theory and practice. Resistance to paying taxes (and other public revenues) in modern conditions of an increased social, economic and especially technological development assumes such serious proportions that authorities and state administration are required to take adequate measures (Đurović-Todorović, Đorđević, 2005, p. 162-172).

Insufficient research into this issue is one of the reasons why we have chosen this topic. A study into tax evasion constitutes a major challenge to a researcher because it is a complex issue and it can be observed from different aspects: legal, economic, financial, social, political, psychological, etc. In this respect, a search for 
a more complete and realistic overview and for valid scientific results requires cooperation between experts from several scientific fields (disciplines) (Anđelković, 2012, p. 45).

\section{The Main Causes of Tax Evasion}

The intensity of tax evasion depends on various factors which have different dimensions in different modern fiscal systems. With respect to classifying the causes of this phenomenon, it is especially interesting, both from the standpoints of financial science and fiscal practice, to ascertain their significance and impact.

A classification of the causes of evasion can primarily be performed by starting from their nature. Thus, they can be divided into subjective and objective. Subjective causes imply some personal aspects relating to taxpayers themselves. These aspects include one's tax awareness, sense of belonging to a particular state, tax mentality, perception of the basic fairness of the tax system, level of education, etc. Objective causes are as follows: the extent of tax burden, the manner of taxation, professional competence and organisation of tax authorities, etc (Klier, 2007, p. 785-800).

An Italian author Giorgetti states some of the main factors which, according to his opinion, have a negative impact upon the propensity of numerous subjects to consciously comply with their tax liabilities. These are as follows:

- Numerous cases of tax evasion which have remained unsanctioned,

- The lack of efficiency of tax provisions with regard to some special categories of taxpayers who have also remained unsanctioned, which created the belief in a large number of citizens that the craftiest are the luckiest,

- Decline in the reputation and respect of tax authorities and their organs in the eyes of a wide circle of taxpayers,

- Frequently weak and unsatisfactory outcome of numerous issues regarding public (state) finances,

- Frequent abuses with respect to the manner of spending the state money.

By analysing the stated causes, one can conclude that the author neglects subjective reasons relating to the personality of a taxpayer, bearing in mind the fact that Italy enjoys the reputation of a country with a very low tax morality.

According to professor Trklja, the most significant factors of illegal evasion are as follows:

- A class and exploitative character of the state,

- The extent of tax burden, 
- Poor control and mild sanctions.

It is a fact that the aforementioned factors are important factors indeed with respect to tax evasion. However, for the purposes of a more comprehensive understanding of the aetiology of the phenomenon, one should not neglect subjective factors.

According to the classification of factors offered by a French author Gaudement one can make a distinction between economic, social, political, psychological, fiscal and technical causes (Gaudement, 2009, p. 330).

\section{Manifestations of Tax Evasion}

The state has always sought to make tax liabilities broader, but also fair. As opposed to the state, legal and natural entities, i.e. taxpayers, have always sought the possibilities of paying less tax without suffering any consequences. These two opposed interests cause different reactions of the participants. The state seeks to introduce the rules of tax procedures in order to collect taxes, i.e. to prevent tax evasion (Milošević, 2005, p. 256).

Tax law recognises two types of evasion:

- Legal (lawful, legitimate) and

- Illegal (unlawful, illegitimate).

Legal evasion implies the use of tax incentives prescribed by the law, as well as the use of loopholes in tax laws, due to their imprecision and ambiguity.

Illegal evasion is present when taxpayers avoid paying taxes and act contrary to legal provisions (Morris, 1977, p. 283).

\subsection{Legal Tax Evasion}

The activities of taxpayers which are not in conflict with the law and have the purpose of avoiding or reducing tax burden are called legal evasion. It is the desire of taxpayers who pay taxes to accomplish their business goals without breaking the law, i.e. by fully complying with tax rules. By complying with tax procedures, taxpayers abide by the law and reduce their tax burden.

Legal tax evasion implies two types of behaviour. However, it is difficult to draw a line of demarcation between them. The aforementioned types of behaviour are legitimate tax evasion and unacceptable tax evasion.

In the tax practice it is difficult to make a difference between these two forms of legal evasion. Legitimate evasion is a form of tax evasion which is in compliance with the intentions of the legislator. The legislator in some cases 
renounces a part of tax revenue, thus achieving the goal of taxation. If, therefore, there is no tax evasion, there is no taxation goal either.

Unacceptable tax evasion implies that a taxpayer through his/her actions intends to play tricks on the provisions of the law and thus avoid and/or reduce their tax burden. Unacceptable tax evasion does not lead to the proclaimed taxation goals, though formally and legally a taxpayer did not violate legal provisions. A taxpayer uses the current legislation, but in the manner which allows for the use of legal loopholes and ambiguities.

The demarcation line between the two types of legal evasion is an important issue which is raised in front of those dealing with financial sciences. Naturally, this is also a specific task for a Tax Administration. By assessing the importance of "recognising" unacceptable legal tax evasion, D. Popović introduces tests into the problem analysis. Every transaction suspected of the lack of legitimacy should be subjected to the tests of intention, the presence of elements of deception, tax savings and a valid decision of the competent tax authorities.

Legal evasion appears in different forms:

- Tax mitigation,

- Reducing or cutting consumption of certain domestic or foreign products,

- Legally organised evasion,

- Finding gaps or loopholes in the legislation and

- Tax incentives.

Tax Mitigation is a form of legal tax evasion in which a taxpayer merely uses tax benefits of a particular region of the land, or of a foreign country. By introducing tax benefits to an area of a certain territorial unit one can affect the growth and development of that particular area and encourage those economic activities which are poorly developed or utterly non-existent. Likewise, tax evasion shall not lead a taxpayer into conflict with the legislation in the case when a taxpayer performs his/her economic activities abroad, in so-called tax havens such as well-known cities/states: Monaco, San Marino, Cyprus, Bahamas, or in the event when a taxpayer changes the place of residence to an address abroad for the purposes of a lower tax burden (Milošević, 2005, p. 264).

Reducing or Cutting Consumption of Certain Domestic or Foreign Products - Refraining from the taxation of certain activities, i.e. reducing consumption of products which are subject to taxation represents the simplest manner of tax evasion, wherewith a taxpayer does not break the law. Reducing consumption or refraining from certain activities cannot be regarded as a violation of the tax legislation. Moreover, such behaviour of consumers, i.e. of the final buyers of taxed goods can be in accordance with the tax policy (Easson, 2003, p. 45). 
The intention behind the increase in tax burden is to reduce consumption of certain products in order to increase exports or protect domestic products by large import costs, should that be the goal of tax policies. By reducing consumption of certain products the state can positively affect the debit and credit sides of the trade balance and of the balance of payments.

Legally Organised Evasions - Legal tax evasion exists even when there is a vertical equity in the economy under the influence of taxation. Namely, if taxed goods go through a smaller number of turnover phases, tax burden is somewhat lower. This means that tax burden is in proportion with the growth in number of turnover phases. Should the number of turnover phases grow, tax burden shall grow as well, and vice versa. Every reduction in tax burden caused by a vertical equity in the economy is not and cannot be considered a violation of tax legislation (Popović, 2006, p. 88).

Finding Gaps or Loopholes in the Legislation - Legal evasion also implies tax avoidance as a result of certain loopholes in the law. By using those loopholes taxpayers seek to use every possibility in order to avoid tax burden by applying various measures and activities. By using services of well-paid tax experts, one can learn that legal tax evasion also includes the cases of specific provisions within the tax legislation which exempt certain taxpayers from paying taxes. Those are legally defined tax incentives. A tax incentive can shortly be defined as a concession of the state to taxpayers on the tax base, tax rates or tax amounts. Tax incentives represent legal tax evasion wanted by the legislator, and every failure to realise tax evasion on the basis of incentives is contrary to the proclaimed fiscal policy. Taxpayers resort to various ways in order to use ambiguities in the law, which are often encountered when collecting one-time tax forms or when introducing new ones, for the purposes of presenting business income in the smallest amounts possible and expenses in the largest amounts possible and thus reducing tax burden and evading taxes.

Tax Incentives - Legal tax evasion also exists in the case when there are certain provisions within tax legislation which exempt certain taxpayers from paying taxes. Those are legally defined tax incentives. A tax incentive can shortly be defined as a concession of the state to taxpayers on the tax base, tax rates or tax amounts. Tax incentives represent legal tax evasion wanted by the legislator, and every failure to realise tax evasion on the basis of incentives is contrary to the proclaimed fiscal policy.

\subsection{Illegal Tax Evasion}

An attempt to avoid complying with tax liabilities very often implies illegal behaviour of their bearers. If a taxpayer, in the process of avoiding taxes, comes in conflict with tax legislation, he/she deals with illegal or illicit tax evasion. Illicit tax 
evasion implies conscious and desired effort to reduce or utterly avoid enforcement of the existing tax liabilities.

The main characteristic of this evasion is the conscious and desired effort of a taxpayer to utterly or partially avoid enforcement of the existing tax liabilities. Hence, a taxpayer is in both formal and material breach of tax law and, therefore, his/her behaviour is in clear contradiction to tax regulations. A characteristic of this form of evasion is that the types and variations of infraction are practically limitless, while the imagination of taxpayers is unpredictable.

Depending on the scales of tax evasion, illegal tax evasion can be either full or partial. One deals with full tax evasion when a taxpayer fails to report the entire amount of the generated income, or the entire property which is subject to taxation, i.e. when a taxpayer conceals transactions which generate tax liability. One deals with partial tax evasion when a taxpayer reports his/her income, property or transactions to the tax authority in a manner which is incomplete or inaccurate, i.e. when by providing false information he/she minimises their tax liability, to which he/she is not entitled.

The forms of tax evasion in the event of illegal evasion are as follows:

- Fraud or infraction,

- Smuggling,

- Double-entry bookkeeping and

- Undeclared work.

\subsubsection{Fraud or Infraction}

Fraud or infraction is a form of illegal evasion whereby taxpayers present inaccurate bookkeeping values, or fail to report necessary facts relevant to determining tax liability (Eichengreen, 2003, p. 78). From the fiscal and legal standpoints infraction exists when tax liability has been legally established. This means that there is a fiscal and legal relationship between a taxpayer and fiscal administration, which differentiates infraction from allowed forms of evasion. In order to declare fraud to be a fiscal offense, it needs to be the result of a positive action (drafting a false or misleading report), or of a negative action (failing to sign a tax report of to abide by certain technicalities).

Depending on who performs illegal tax evasion, some authors make a difference between a unilateral and a bilateral evasion. If a taxpayer performs tax evasion on his/her own, one deals with a unilateral evasion. If tax evasion is aided or tolerated by a tax officer, one deals with a bilateral evasion. 


\subsubsection{Smuggling}

Another form of illegal or illicit tax evasion includes evasion of indirect taxes value added taxes, excise and custom duties, both in the event of the cross-border movement of goods and movement of goods inside the national borders. From the standpoint of its effects, it is not much different from tax fraud (infraction). This phenomenon is not given sufficient attention either in scientific or in professional public, and it causes negative financial, economic, social and political consequences.

In our customs system, according to the level of customs control possibilities, all violations of customs regulations (customs offences) are divided into smuggling, customs fraud and customs irregularities. In the event of smuggling, the goods are completely inaccessible to customs inspection, while in the event of customs fraud the goods are accessible to customs inspection and the offender seeks in various ways to evade customs duties. Customs irregularities are the mildest customs offences. Aside from the aforementioned three types of customs offences, there is also the fourth type - the negligent disposal of customs goods. It is an independent customs offense and it encompasses buying and selling, distribution, storage and concealment, receiving gifts and using goods which are assumed to be either smuggled, or a result of customs fraud. Nevertheless, according to its characteristics, this customs offense may partially be categorised as smuggling and partially as customs fraud.

The most typical and common manners of illegal sales tax evasion in modern fiscal systems which are familiar with value added taxes are sales without invoices and invoices without sales. The essence of these actions is the fact that by issuing an invoice without sales one reduces the tax base, while in the event of sale without invoices one increases the deductions or tax return.

Evasion of indirect taxes is characterised by organised tax evaders who can even be considered professionals. In the event of other forms of taxes (personal income taxes, other income taxes) a taxpayer himself/herself seeks to avoid taxes. Such attempts at evasion are considered to be the work of amateurs (though even these taxpayers increasingly consult with and seek help from tax advisers).

\subsubsection{Double-Entry Bookkeeping}

The aim of bookkeeping, which is taxpayers' legal obligation, is to ascertain the actual capacity of taxpayers, which results in either suppression or reduction of tax evasion to socially acceptable limits. However, the practice denies this claim, because numerous taxpayers falsify the results of their business activities, i.e. they fix the ledger, as they say in the business jargon, before submitting financial 
reports to the Business Registers Agency, as well as the tax balance to tax authorities.

In almost all modern states, keeping books and other auxiliary documents is an obligation of taxpayers which serves to establish the actual income of a company or individuals engaged in independent activities. By means of suitable legal provisions it is determined under which conditions one needs to keep books so that they can serve as a basis for determining tax liabilities (Simon and Christopher, 2000, p. 129).

In business ledgers there are specific places which can be suitable for concealment. This matter primarily concerns the exaggeration of general business expenses. Tax authorities sometimes find themselves in a difficult and delicate situation in the course of evaluation and qualification of the said expenses the aim of which is to ascertain proper income, and consequently the income tax. Taxpayers have a myriad of possibilities to use the general expenses to cover some other expenditure which is not the actual cost of a taxpayer.

\subsubsection{Undeclared Work}

Undeclared work is one of the activities which participate in the total size of the economy of a state, except that this activity is illegal and concealed. This activity enables one to earn without paying taxes, in a manner which is not socially organised and sanctioned. As a result, in the event of undeclared work one can offer services and products which are cheaper than those offered by legal economy. Undeclared work is present in different areas of economic and social life. Both natural and legal entities resort to this sort of work or activities. Unregistered production, unregistered trade, conducting activities without permits and licences, undocumented additional work, unregistered employees - these are different forms of behaviour devised to generate income which is not controlled by tax authorities, and hence implies tax evasion.

Tanzi gave a simple and acceptable definition of a parallel or concealed economy. It is the gross domestic product which, due to failure to report it or due to decrease in reported amounts, is not covered by official statistics (Tanzi, 2003, p. 248).

Starting from the set aim of the analysis (establishing parallel economy, i.e. undeclared work as a modality of evasion), it is possible to use a somewhat more complete definition according to which parallel economy is a set of diverse activities which have not been presented in the official statistics, including the gross domestic product, though they contribute to its total value (Lončarić, 2006, p. 430). 
Undeclared work, i.e. parallel economy, as a basis of economic and social stratification, is an elusive and unsolvable issue, even for many other modern countries. Tax authorities and the legislators themselves remain powerless in front of those phenomena and processes which indicate that even secondary taxation was not successful enough. Hence, they are trying to find the way out of this enchanted circle by introducing property taxes, which objectively imply tertiary taxation.

\section{The Size and Structure of Tax Evasion Detected by the Tax Audit in the Republic of Serbia}

Tax audit is the third main function of a Tax Administration. There is no tax system which can function efficiently without a well organised and conducted tax audit. Inadequate and poor quality audit is most commonly the weakest link in the chain of measures taken with the aim of implementing the tax system. In this respect, tax audit is also the most important function of tax authorities, as a form of verification of other functions of these organs (determining and collecting taxes) (Vasić, 2011, p. 152).

Our state is immensely compromised by avoiding tax liabilities of all kinds. A significant contribution to suppressing evasion has been given by the workers of the Tax Administration, especially by tax inspectors. This observation is supported by the data on the amount of evaded public revenues detected by tax audit in the period between 2007 and 2014.

The size and structure of tax evasion shall be followed analytically through the following: 1) the total number of performed audits with the number of audits in the course of which irregularities have been detected; 2) the total number of tax evasion cases detected by tax audit at the level of the Republic of Serbia. Thus established size of tax evasion shall be considered structurally, per tax forms. For analytical purposes, the size and structure of tax evasion shall be observed through 1) relative shares in the total size per selected criteria, 2) dynamic changes of the established size of evasion and relative structures. Tax audit is the third main function of a Tax Administration. There is no tax system which can function efficiently without a well organised and conducted tax audit. Inadequate and poor quality audit is most commonly the weakest link in the chain of measures taken with the aim of implementing the tax system. In this respect, tax audit is also the most important function of tax authorities, as a form of verification of other functions of these organs (determining and collecting taxes) (Vasić, 2011, p. 152).

Our state is immensely compromised by avoiding tax liabilities of all kinds. A significant contribution to suppressing evasion has been given by the workers of the Tax Administration, especially by tax inspectors. This observation is supported by the data on the amount of evaded public revenues detected by tax audit in the period between 2007 and 2014. 
The size and structure of tax evasion shall be followed analytically through the following: 1) the total number of performed audits with the number of audits in the course of which irregularities have been detected; 2) the total number of tax evasion cases detected by tax audit at the level of the Republic of Serbia. Thus established size of tax evasion shall be considered structurally, per tax forms. For analytical purposes, the size and structure of tax evasion shall be observed through 1) relative shares in the total size per selected criteria, 2) dynamic changes of the established size of evasion and relative structures.

\subsection{Tax Evasion Detected by the Tax Audit in the Republic of Serbia for the Period between 2007 and 2014.}

In the following table the authors present data regarding the total detected tax evasion per all tax forms, where the procedure of deflation has been used for the purposes of measuring detected tax evasions by means of converting financial amounts of evasion in the observed years into constant currency in 2014. On the basis of the evasion thus measured, the growth rates of tax evasion have been established. By comparing these data with the data regarding the number of performed audits, the authors have reached the amount of evasion per audit, and the final part of the table represents the growth rate of the detected tax evasion per all tax forms per one audit.

Table 1. Detected tax evasion in the Republic of Serbia for the period between 2007 and 2014

\begin{tabular}{|c|c|c|c|c|}
\hline Year & $\begin{array}{c}\text { Total evasion in } \\
\text { billions of constant } \\
\text { currency in 2014. }\end{array}$ & $\begin{array}{c}\text { Growth rate of the } \\
\text { tax evasion in \% }\end{array}$ & $\begin{array}{c}\text { The amount of } \\
\text { evasion per audit } \\
\text { in RSD }\end{array}$ & $\begin{array}{c}\text { The growth rate } \\
\text { of evasion per } \\
\text { audit }\end{array}$ \\
\hline $\mathbf{1}$ & $\mathbf{2}$ & $\mathbf{3}$ & $\mathbf{4}$ & $\mathbf{5}$ \\
\hline 2007. & 26.883 & & 239.090 & \\
\hline 2008. & 41.712 & 55,2 & 576.170 & 141 \\
\hline 2009. & 30.830 & $-26,1$ & 653.959 & 13,5 \\
\hline 2010. & 30.440 & $-1,3$ & 687.993 & 5,2 \\
\hline 2011. & 29.735 & $-2,3$ & 779.901 & 13,4 \\
\hline 2012. & 24.183 & $-18,7$ & 848.933 & 8,9 \\
\hline 2013. & 23.613 & $-2,35$ & 786.954 & $-7,3$ \\
\hline 2014. & 49.071 & 107,81 & 989.354 & 25,7 \\
\hline Average & & 16,08 & & 28,6 \\
\hline
\end{tabular}

Source: The Ministry of Finance and Economy, Tax Administration, 2014; the Annual Work Report of Tax Audit, page 46 (when using the data the author performed the necessary calculations)

The data presented in the previous table enable one to follow the flow of evasion in absolute and relative amounts in the observed years. The total size of 
evasion in constant currency in 2014 indicates that which was shown by the relative indicator in the form of evasion relating to the total public revenue. In the starting year, evasion amounted to 27 billion RSD, only to become expanded to 42 billion RSD in the year to follow, then it became stabilised in the following three years at the level of 30 billion RSD, and then it began a slight downward trend. In the last observed year (2014) the absolute size of evasion (49 billion RSD) was the highest in value, higher than it had been in the first observed year. All actual annual rates of changes in the size of tax evasion were negative, except in the years of 2008 and 2014, but due to the amount of detected tax evasion in 2008 and 2014 the average seven-year rate was positive (16,08\%).

The second part of the presented table offers the possibility to check the relative size of evasion in the Republic of Serbia. The first indicator - evasion per audit - enables one to check the efficiency of the work of tax audits in the observed years, since the calculation was based on comparable constant currency in 2014. The total size of evasion per one tax audit, though evasion in the latter years decreased both absolutely and relatively, had a steady upward trend, even in those years when one detects the stagnation of economical activities and total public revenue. This directly proves that tax audits have constantly increased the efficiency of their work, which grew at an average annual rate of $28,6 \%$.

\subsection{The Structure of Tax Evasion per Tax Forms}

In this segment the authors compare the relative significance of tax evasion per every tax form. To this purpose the authors shall use the calculated average annual rates of tax evasion in the observed period between 2007 and 2014, which together form the overall rate of tax evasion of $13,6 \%$ and whose share in the total relative rate shows the relative significance of each individual rate of tax evasion per every particular tax form.

Therefore, in the observed period the dynamics of tax evasion per tax forms was mostly concentrated on two forms of public revenue: social security contribution with a share of $33,5 \%$ and the VAT with a share of $25 \%$. One could say that the scope of significance of these public revenues has influenced the tendency of tax payers to avoid calculating taxes and paying them. On the other hand, one could equally say that the same causes have induced tax audit to direct their attention to these tax forms and thus detect the relatively largest size of tax evasion.

The presented structure of tax evasion shows the dynamics of the movement of the tax evasion degree per observed years and it is not fully influenced by the total size of evasion per tax forms. The aforementioned two forms of public revenue, according to their size in the observed group, would take 58,5\% of the total tax evasion. The dynamic structure has shown that even other forms of tax evasion, 
such as income tax $(14,9 \%)$, other taxes $(13 \%)$ and personal income tax $(7,5 \%)$ can significantly influence the inclinations of tax payers towards tax evasion, as well as the inclination of tax audit towards directing themselves to all tax forms in the full width of their manifestations.

Table 2. The structure of tax evasion per tax forms in the Republic of Serbia between 2007 and 2014

\begin{tabular}{|c|c|c|}
\hline Tax form & $\begin{array}{c}\text { The average \% of evasion of } \\
\text { individual tax forms in revenues } \\
\text { collected from the said taxes }\end{array}$ & $\begin{array}{c}\text { The structure of tax evasion } \\
\text { per tax forms in (\%) }\end{array}$ \\
\hline VAT & 3,4 & 25,0 \\
\hline Income tax & 2,02 & 14,9 \\
\hline Excise & 0,98 & 7,2 \\
\hline Contributions & 4,55 & 33,5 \\
\hline Personal income tax & 1,02 & 7,5 \\
\hline Other income & 1,63 & 12,0 \\
\hline Total & 13,6 & 100 \\
\hline
\end{tabular}

Source: The Ministry of Finance and Economy, Tax Administration, 2014; the Annual Work Report of Tax Audit, page 46, Public Finance Bulletin for August 2014, Belgrade, page 32 (when using the data the author performed the necessary calculations)

The last conclusion can be drawn from the fact that the lowest dynamics of tax evasion in the observed group, noted in the excise with the share of $7,2 \%$, confirms the earlier insight that the manner of calculation and payment is decisive in tax evasion. The proscribed excise in a form of a single and fixed amount disables taxpayers to avoid paying this public revenue on the basis of financial statement, but also enables tax audit to easily and rapidly detect tax evasion. From the presented results one can draw a general conclusion that the complexity of the mechanism of financial statements and payments significantly contributes to the size and dynamics of tax evasion, and not merely to the tendency of taxpayers to avoid taxes or to the rigour of tax audit. In this manner, the authors have established another possible cause of the effectiveness of tax audit which does not necessarily depend on the organisation of tax authorities.

\subsection{The Share of Tax Evasion in the Total Revenue in Serbia in the Period between 2009 and 2014}

In the following table the authors present the total revenue of the Republic of Serbia for the period between 2009 and 2014, the total detected tax evasion in constant currency and the percentage of evasion in the total revenue for the observed period.

One of the possible manners of tracking structural changes in the total size of evasion is through its relationship with the total (public) revenue. According to 
available data regarding evasion and public revenue in Serbia in the observed period between 2009 and 2014, the total size of evasion was 4,2\% on average of all pubic revenues. It is a relatively large size of evasion of the total public revenues in Serbia.

Table 3. The share of evasion in the total budget revenues in the Republic of Serbia in the period between 2009 and 2014

\begin{tabular}{|c|c|c|c|}
\hline Year & $\begin{array}{c}\text { Total revenues in millions of } \\
\text { constant currency }\end{array}$ & $\begin{array}{c}\text { Tax evasion in millions of } \\
\text { constant currency }\end{array}$ & $\begin{array}{c}\text { \% of evasion in } \\
\text { total revenues }\end{array}$ \\
\hline 2009. & $446.997,20$ & $17.160,00$ & 3,84 \\
\hline 2010. & $494.139,20$ & $30.007,70$ & 6,07 \\
\hline 2011. & $581.841,50$ & $23.679,10$ & 4,06 \\
\hline 2012. & $639.600,30$ & $25.950,70$ & 4,05 \\
\hline 2013. & $698.756,20$ & $27.919,70$ & 3,99 \\
\hline 2014. & $655.971,00$ & $24.182,60$ & 3,39 \\
\hline Average & $3.517 .305,40$ & $148.899,80$ & 4,23 \\
\hline
\end{tabular}

Source: The Ministry of Finance and Economy, Tax Administration, 2014; the Annual Work Report of Tax Audit, page 46, Public Finance Bulletin for August 2014, Belgrade, page 32 (when using the data the author performed the necessary calculations)

In the second segment of the observed period one can observe a decline in the relative relationship between the size of evasion and the total public revenue. The declining trend coincides with the period of global economic crisis, when the economy of Serbia shifted to the zone of negative and stagnating growth rates. One could assert that the stagnation of economic activities in Serbia influenced the decline in the total size of evasion in comparison to the total amount of public revenues (from $4 \%$ to $3,4 \%$ ), although the amount of public revenues for the same period was stagnating as well.

\section{The Effects of Tax Audit in the Process of Suppressing Tax Evasion}

According to the data which the authors obtained through conversion, the share of tax evasion per all tax forms in relation to the gross domestic product for the countries in transition for the observed period, one can conclude that in Slovenia that percentage was the lowest, while in Russia it was the highest. Thus established evasion on the basis of performed tax audits in the countries in transition is almost as twice as lower than the actual. The reasons can be sought in the fact that in the observed period tax audits did not encompass all taxpayers who had evaded taxes in various ways. 
Table 4. The share of detected tax evasion in GDP of the selected countries in transition and Serbia for the period between 2012 and 2014

\begin{tabular}{|c|c|c|c|c|}
\hline \multirow{2}{*}{ Countries } & \multicolumn{3}{|c|}{ Detected evasion in GDP (\%) } & \multirow{2}{*}{ Average per country (\%) } \\
\cline { 2 - 4 } & $\mathbf{2 0 1 2 .}$ & $\mathbf{2 0 1 3 .}$ & $\mathbf{2 0 1 4 .}$ & 0,76 \\
\hline Russia & 0,76 & 0,64 & 0,90 & 0,67 \\
\hline Poland & 0,66 & 0,59 & 0,78 & 0,30 \\
\hline Czech Republic & 0,31 & 0,29 & 0,30 & 0,55 \\
\hline Croatia & 0,58 & 0,49 & 0,59 & 0,25 \\
\hline Slovenia & 0,28 & 0,27 & 0,22 & 0,57 \\
\hline Slovakia & 0,48 & 0,59 & 0,66 & 0,51 \\
\hline Annual average & 0,51 & 0,47 & 0,57 & 0,94 \\
\hline Serbia & 1,03 & 0,88 & 0,92 & 183,5 \\
\hline Relation RS/Average & 201,9 & 187,23 & 161,4 & \\
\hline
\end{tabular}

Source: The Ministry of Finance and Economy, Tax Administration, in 2014, the Annual Work Report of Tax Audit, page 46, Public Finance Bulletin for August 2014, Belgrade, page 32.

The observed group of the countries in transition achieved the average and relative size of evasion of $0,5 \%$, in relation to the GDP, which is somewhat lower level of evasion than in the observed developed countries (0,56\%). This unexpected relationship is most likely the result of disorganisation of tax administrations in the countries in transition, because it is quite logical to assume that in the period of transition and development of a new economic system the size of evasion was much larger than in developed countries. On the other hand, one can assume that evasion can be observed as a phenomenon typical of every form of economic organisation, i.e. that the tendency towards tax evasion is stable in all countries.

The lowest relative level of tax evasion in the countries in transition was achieved in Slovenia $(0,25 \%)$ and Czech Republic $(0,30 \%)$. Since those are the countries which are organisation wise the most successful in this group with respect to the development of a new economic system, one can deduce that they have successfully developed their tax systems as well, including its audit section. This confirms the main hypothesis which deals with the significance of tax audit for the suppression of tax evasion in national economies. On the other hand, in the observed countries in transition, the relatively largest size of tax evasion was achieved in Russia $(0,76 \%)$ which is known to have the biggest organisational and administrative issues in the process of developing a new economy system. This also confirms the set hypothesis.

Since Serbia is also one of the countries in the process of transition, and it is also specific because of its ten-year delay in the intensity of transitional changes, the relative indicator of the achieved size of evasion in GDP, which is $83 \%$ higher 
(index 183,5) than the average of the selected countries in transition, shows that it is a very large size of evasion. Likewise, this also shows that the manner of organisation of the Tax Administration in Serbia is at a much lower level than in other countries in transition, especially in the most successful ones (4 times lower than in Slovenia). Thus, the attention which needs to be paid to improving tax audit is of utmost analytical and practical significance.

\section{Conclusion}

Due to serious consequences of tax evasion, it is necessary to extend the tax system modelled on developed market economies, to modernise the Tax Administration and significantly improve the co-operation between its segments. It is necessary to work on suiting material and spiritual needs of the citizens, as well as to improve overall living conditions, educate tax staff, efficiently discover and publish serious cases of tax evasion with the aim of preventing similar cases in the future, etc.

High-value assets are out of the scope of the tax system. It is a consequence of voluntary reporting of tax liabilities. Due to tardiness of the cadastre and illegal construction a large number of taxpayers have not been registered or filed, which also contributes to high tax evasion in the field of property tax.

For the purposes of preventing tax evasion the legislator prescribed offenses in the secondary criminal legislation which protect public revenues. However, the atmosphere of lawlessness, as well as the protection of perpetrators of these crimes by the holders of economic and political power influences the decline in morality and devaluation of penal policy. This encourages taxpayers to continue with the practice of tax evasion (public revenues).

A relatively strong fiscal pressure for our economic possibilities has a negative impact on economic conditions and growth. In spite of fiscal pressure, the basic needs in the field of general and common consumption are still very difficult to meet, and even when they are met, it is achieved at a very basic level. The tax structure in our country is similar to tax structures of developed countries. In reality, however, our country mostly relies on the consumption tax. These taxes comprise $50 \%$ of the budget of the Republic of Serbia. It indicates that a large portion of the tax force remains untaxed, which means that our tax structure has practically remained the same as before the reforms, which further indicates that the main goals of the fiscal reform have not been achieved.

It is necessary to introduce synthetic taxes on personal income which would comprise all revenues generated by taxpayers in the course of a year. That would mean that citizens with the largest income would pay the largest amount of taxes. That would prevent the current taxation of individual income of the citizens, and as a result the state would generate a larger amount of public revenues. 
Traditional attitude and behaviour of the administration must change towards co-operating, providing advice and protecting the rights of taxpayers. Improvement of relationships between Tax Administration and taxpayers could result in the increase in collectible tax liabilities, establishment of trust in the tax system and avoidance of discomfort regarding the retention of skilled staff.

Tightening of the punitive policy in the field of public revenues would somewhat contribute to the suppression of tax evasion. In that direction, punitive policy should be established in such a manner that financial penalties are imposed in the amount which significantly exceeds the amount of evaded taxes. The aforementioned imposes the need to train and adjust suitable social subjects to perform their functions in the new system of tax relations. The process of transformation of the tax system should not be understood as routine and easy. Organisational difficulties, working conditions, new forms of tax evasion disable the creators of tax legislation to deal with the issues within their scope of interest in a proper manner. It will take some more time to build the tax system and adjust it to the market conditions while simultaneously reducing tax evasion to the minimum level.

\section{References}

Anđelković, M. (2012). Public finance and financial law. Niš: Publications Center of the Faculty of Law Niš.

Đurović-Todorović, J. \& Djordjevic, M. (2005). Tax evasion as a brake on the development of the Republic of Serbia. Ekonomist 1, 29-35.

Easson, A. (2003). Tax Incentives. Washington DC: World Bank Institute.

Eichengreen, B. (2003). Institution for Fiscal Stability (Working Paper PEIF-14), Berkeley, Institute of European Studies.

Gaudement, P. M. (2009). Editions Montchrestien Finances Publiques-Emprunt et impot, Montchrestien: Northwestern University.

Harvey, S. R. (2002). Public Finance. (6 ${ }^{\text {th }}$ ed). New York: McGraw-Hill.

Klier, D. (2007). The current issue of disclosure, reporting and processing of tax evasion. Croatian Annual of Criminal Law and Practice, 2, 785-800.

Lončarić Horvat, O. (2006). Parallel economy - and for or against. Proceedings of the Faculty of Law, 3 (4), 430-441.

Milosevic, G. (2005). Taxes and tax evasion. Official Gazette, 256-264.

Morris, D. (1977). The Economic System in the UK. Oxford: University Press.

Popović, D. (2006). Tax law (General part), Belgrade, Cekos-in.

Simon, J. \& Christopher, N. (2000). The Economics of Taxation. Prentice Hall, 129-134.

Tanzi, V. (2003). Comparative Tax Law, Kluwer Law Internataional Journal, 428-437.

The Ministry of Finance (2014). Annual report (The Tax Administration), Belgrade, The Department for Education and Communication.

Vasic, Z. (2011). The possibility of improving the work of the Tax Administration in cooperation with the audited organizations and higher education institutions. The Union of Accountants and Auditors of Serbia, 152-159. 


\section{TERENSKA KONTROLA KAO VAŽAN FAKTOR ZA SUZBIJANJE PORESKE EVAZIJE}

Apstrakt: Činjenica da se ogroman deo javnih prihoda izgubi kroz poresku evaziju ukazuje na neminovnost preduzimanja različitih mera za njeno suzbijanje. Prema poslednjim statističkim podacima, 30\% bruto društvenog proizvoda odliva se kroz poresku evaziju. Cilj ovog rada jeste da ukaže na sistematizaciju materije koja se odnosi na ocenu efikasnosti poreske kontrole kao stožera smanjenja poreske evazije i sive ekonomije kod nas. Metodologija podrazumeva deskriptivno istraživanje. Prikupljeni podaci detaljno su analizirani korišćenjem prostih matematičkih funkcija. Zbog teških posledica poreske evazije, neophodno je izvršiti dogradnju poreskog sistema po ugledu na razvijene tržišne privrede. Neophodna je modernizacija poreske administracije, kao i poboljšanje saradnje svih njenih segmenata. Trebalo bi uvesti sintetički porez na dohodak građana kojim bi se zahvatili svi prihodi koje obveznik ostvari u toku godine. Kada bi svi poreski obveznici izmirivali svoje poreske obaveze stvorio bi se prostor za smanjenje poreskog opterećenja. U zemljama u kojima funkcioniše pravna država, samo se „najhrabriji“ usuđuju da izbegnu plaćanje poreza. Većina zemalja preduzima niz mera u cilju suzbijanja poreske evazije i sive ekonomije. Međutim, uspešnost borbe nije svuda ista.

Ključne reči: porez, poreska evazija, suzbijanje, terenska kontrola, poreski sistem.

\section{Authors' biographies}

Miodrag Todorović works in the Tax Administration Department in Leskovac, as a tax inspector. He received his $\mathrm{PhD}$ at the Faculty of Economics in Niš. Since October 2014, he has worked also as a Professor of Public Finance and Financial Law at the International University in Novi Pazar. His research interests include finance, monetary policy and monetary integration.

Ivan Stanković works in the Branch of the Tax Administration in Leskovac as a Branch Director. He received his $\mathrm{PhD}$ at the Faculty of Economics and Justice in Novi Sad. He teaches Financial Law at the Faculty of Economics and Justice in Novi Sad. The main areas of interest are tax evasion and tax offenses.

Samir Ljajić has been a manager of a branch of the International University of Novi Pazar since its establishment in 2003. He is a PhD student at the Department of Economy of the above mentioned University, and as of 2015 a teaching assistant of public finances and financial law. His main research interests are finances and monetary policy. 